\title{
Impacts of natural disasters on smallholder farmers: gaps and recommendations
}

\author{
Tejendra Chapagain * (D) and Manish N. Raizada
}

\begin{abstract}
Here, we review the impacts of recent natural disasters in developing countries on rural agriculture and livelihoods with the objective of understanding gaps and providing recommendations. Lessons from these disasters demonstrate that national governments, aid agencies, and international/non-governmental organizations (I/NGOs) are effective primarily at distributing short-term products (e.g. food packages and tarpaulin) to cities. Such products are inexpensive, simple to procure, and easily quantifiable for donors. Unfortunately, the literature suggests that many national governments and foreign NGOs are ineffective at assisting rural farmers in the short and long term. Given that the global community is somewhat effective at distributing short-term products, we suggest that a similar strategy should be developed for rural areas, but focusing on products that can assist farm households. There appears to be a gap in knowledge of effective products that can target such households after a disaster. We propose an emergency sustainable agriculture kit (eSAK) framework for disaster relief in rural areas that involves a comprehensive list of products that can be combined into packages to address the needs of shelter, hunger, first aid, seeds, preservation of indigenous crop varieties, and post-disaster labour shortages. We also propose ideas on how to re-purpose relief products provided to urban areas to assist with farm needs. Products highlighted are rolls of agricultural-grade plastics, low-oxygen grain storage bags, waterproof gardening gloves, multi-use shovels, seeds of early maturing crops, fertilizers, inexpensive farming tools, temporary food support, and first-aid kits. These products are needed, inexpensive, labour efficient, compact, lightweight, available/procurable on a large scale, simple, and re- usable. Furthermore, correct use and re-purposing of the products can be explained using accompanying graphical illustrations, which is critical for rural illiterate households. As distribution to rural areas is a challenge, especially after a disaster, we propose the use of pre-existing alcohol/cigarette/snackfood distribution networks as a novel strategy for rural disaster relief. These efforts must be in partnership with local officials and grassroots organizations, with dedicated funding from governments and international aid agencies. It is hoped that global stakeholders will benefit from these recommendations to assist affected farmers after a crisis.
\end{abstract}

Keywords: Natural disaster, Food security, Rural, Agriculture, Shelter, Hunger, First aid, Indigenous seeds, Labour

\section{Background}

Earthquakes, landslides, flood, drought, fires, and hailstorms are some of the natural calamities that occur every year, at any point, and anywhere, causing threats to the livelihoods of smallholder farmers and their food security. Disasters can cause loss of human and animal

\footnotetext{
${ }^{*}$ Correspondence: tejendra@uoguelph.ca

Department of Plant Agriculture, University of Guelph, Guelph, ON, Canada
}

life, field crops, stored seeds, agricultural equipment/ materials, and their supply systems (e.g. infrastructure) as well as associated indigenous knowledge, thus disrupting not only the immediate growing season but also future seasons $[1,2]$. Rural regions of the developing world can be remote, with high concentrations of mass poverty [3, 4], food insecurity [4-6], and illiteracy $[4,7]$; hence access to food, shelter, and communication related to relief and recovery is a challenge after a disaster. In rural areas, farmers strongly rely on natural

\section{Ciomed Central}

(c) The Author(s) 2017. This article is distributed under the terms of the Creative Commons Attribution 4.0 International License (http://creativecommons.org/licenses/by/4.0/), which permits unrestricted use, distribution, and reproduction in any medium, provided you give appropriate credit to the original author(s) and the source, provide a link to the Creative Commons license, and indicate if changes were made. The Creative Commons Public Domain Dedication waiver (http://creativecommons.org/ publicdomain/zero/1.0/) applies to the data made available in this article, unless otherwise stated. 
resources $[8,9]$ and have no alternative source of income or employment, making them more vulnerable to a crisis. Women and children, those most responsible for onfarm labour in developing countries, are most affected by post-traumatic stress after a disaster [10]. After disasters, intense media focus occurs on the cities where the images are most dramatic, whereas the needs and issues of rural farm families are often neglected [11, 12]. Apart from disasters that occur directly in rural areas, damage to cities also impacts rural families, as urban-torural migration causes food shortages and the consumption of planting materials as occurred after the Haitian earthquake in 2010 [2]. All these factors may lead to a long-term disaster in rural areas as witnessed in Haiti $[13,14]$. Therefore, after a natural disaster, rural areas require emergency interventions to maintain livelihoods and food security $[14,15]$, and a longer-term integrated recovery plan [16] to minimize the possibility of a secondary disaster, as inexpensively as possible given limited local financial resources.

Developing nations are especially vulnerable to rural disasters as the majority of livelihoods $(50-95 \%$ of the population) are based on farming [4, 17]. Despite highly publicized trends towards urbanization, in 2030, it is expected that over $55 \%$ of the population in developing countries will continue to live in rural areas [7]. A decline in the dollar-a-day poverty rate in rural areas has been reported in East Asia and the Pacific region; however, rural poverty is rising notably in sub-Saharan Africa and South Asia [18]. According to the United Nation's World Food Programme, three-quarters of hungry people live in rural areas [19], of which $98 \%$ are in developing countries [6].

The current literature regarding natural disasters has not focused on coping efforts to assist farmers, but rather on the post-disaster impacts on rural livelihoods [12], household economy, food and nutritional security [12, 20-22], seed systems security [23, 24], soil fertility [25], physical and mental health [26, 27], population displacement [28], and long-term human migration [29] from the affected regions. A few studies have discussed government and non-governmental humanitarian systems [30,31] and the efficiency of their distribution channels [32]. The objectives of this paper are: (1) to review recent natural disasters that have affected farmers in developing nations, as case studies; (2) propose criteria for effective interventions for farmers; (3) suggest high-priority interventions based on these criteria; and finally (4) discuss distribution and logistics strategies to reach affected rural areas, with the goal of reviving agriculture and maintaining life and livelihoods in disaster-affected areas.

\section{Examples of recent natural disasters that impacted rural areas}

Table 1 summarizes the peer-reviewed literature pertaining to recent major natural disasters in developing nations (Nepal, Haiti, Pakistan, Indonesia, Sri Lanka, Thailand, India, and Ethiopia), their impact on rural lives, aid responses by national and international communities, the outcomes of these interventions, and challenges. These disasters caused significant damage to the livelihoods and food security of smallholder farmers in each respective country:

\section{Nepal earthquake}

Nepal, where more than $85 \%$ of the people in rural areas depend on agriculture $[4,33]$, was hit hard by a deadly 7.8 magnitude quake that affected 8 million people in the midand high-hill districts. A large population was left homeless and sought shelter in makeshift tents and tarpaulin. The earthquake affected nearly one million smallholder farmers across 24 districts, of which households headed by women and the elderly suffered the most due to migration of male members to nearby cities and abroad [34]. The estimated total value of damage and loss to the agriculture sector was USD 284 million [35]. The earthquake had a serious impact on the livelihoods of rural farmers as massive damage and losses occurred to crop lands, physical infrastructure, polyhouses, livestock shelters, agricultural tools, equipment, and machinery [35]. Stored seeds were buried under the rubble. Farmers had no storage facilities for the standing spring rice and maize crops.

Aid agencies, I/NGOs, and the national government were involved in providing immediate necessities such as food, water, shelter kits, and hygiene kits to the households affected by the earthquake. However, emergency relief provisions to rural areas, already the food-deficit regions of the country [36], were appallingly inadequate due to poor road connections in the hills and/or destruction of existing infrastructure [37]. Longer-term recovery efforts for farmers were limited to regions near cities and reached only thousands of farmers [34]. These efforts focused on enhancing the production of crops, livestock, and fisheries by replacing tools and machinery, restocking of lost animal stock, reconstruction of agriculture infrastructure, and restoration of small farmer-managed irrigation systems [35]. Some farmers were supported with seeds of rice, wheat, maize, cowpea and beans, and vegetables along with grain storage bags and animal feed supplements to provide months of staple food and to ensure they did not miss the immediate planting season $[34,38]$. In addition, a small number of farmers near cities received plastic tunnels (greenhouses) and drip irrigation equipment to encourage off-season vegetable production 


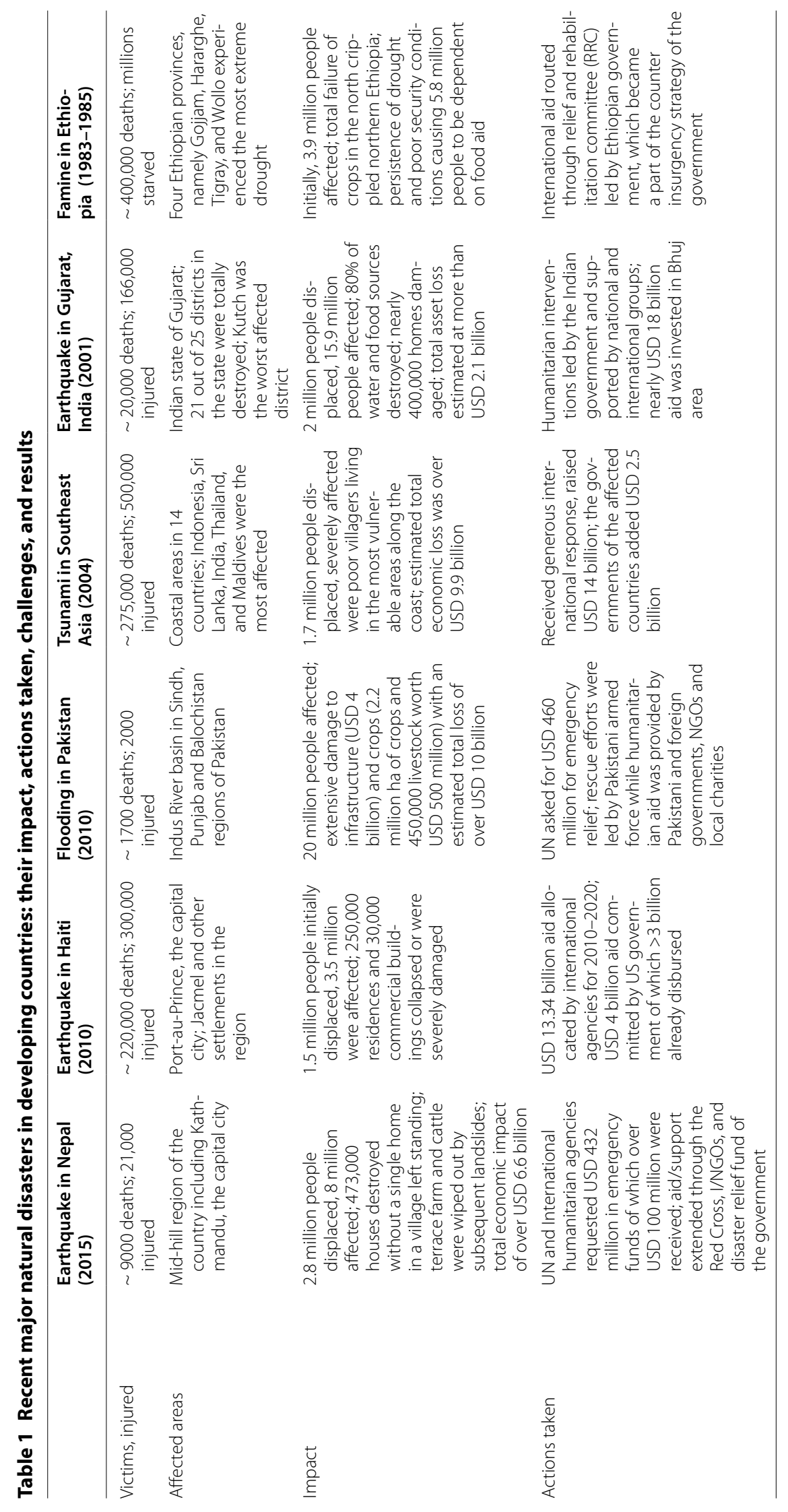




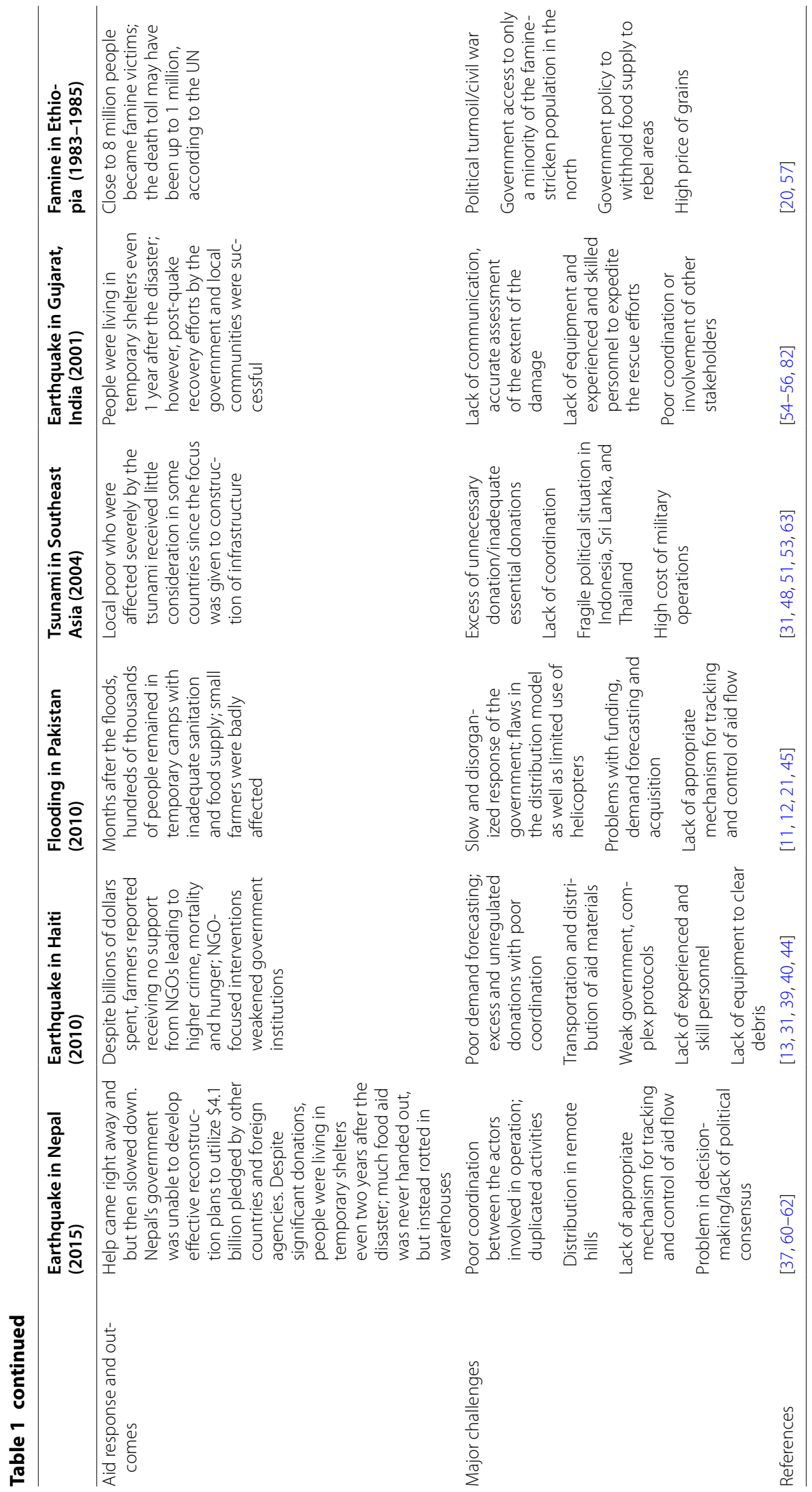


which generated limited impact due to incomplete agricultural packages (e.g. early maturing seeds and fertilizer) and delays in their distribution. Remoteness, lack of disaster preparedness, political instability and poor leadership, bad governance, and poor coordination among international, national, and local actors hindered the relief and reconstruction efforts in the remote hills and mountains.

\section{Haitian earthquake}

An earthquake measuring 7.0 on the Richter scale devastated and crippled the small, underdeveloped Caribbean nation of Haiti in 2010, impacting 25\% of the national population. The majority of the devastation occurred in the capital city of Port-au-Prince, where approximately 300,000 people perished, and over 2 million were displaced and left homeless [39]. Moreover, it is estimated that 1.3 million people living in Port-au-Prince had to reside in temporary shelters or tents located throughout the city, while up to 600,000 of its residents fled to rural areas of the country [40]. The urban-to-rural migration led to food shortages and loss of biodiversity in rural areas due to the consumption of planting materials [2]. The estimated total value of damage and loss to the agriculture sector was about USD 149 million [41]. Damage to this sector included silting of irrigated plots and cracking of irrigation canals [42], as well as reported losses of seed stocks and storage facilities.

Emergency relief provisions provided by aid agencies and I/NGOs, especially necessities such as tents, potable water, food and basic health care, were mostly focused on cities. Billions of dollars were spent by international funding agencies that promoted NGOs as substitutes for the state which weakened the government $[13,43]$. Nevertheless, farmers reported receiving no support, leading to increased crime, mortality, and hunger [44]. There were limited efforts by FAO to support the Government of Haiti's Programme of Action to rebuild the agricultural sector, improve food security, and create employment and livelihood opportunities for the rural population and internally displaced people [42]. The support included: distribution of seeds and planting materials, hand tools, fertilizers, small animals and fishing materials, promotion of fruit tree crops for soil conservation, establishment of emergency seed stocks, seed storage and conservation, and reconstruction and reinforcement of infrastructure through cash-for-work programmes. However, no or very little attention was given to improve soil fertility (e.g. hillside erosion control, legume integration, cover crops, reforestation, livestock improvement as well as subsidies for inorganic fertilizers to quickly help rebuild soil fertility) that led to chronic poverty and malnutrition [25].

\section{Pakistan floods}

Similarly, a tragic and massive flood in Pakistan affected most of the country from north to south, displacing more than 20 million people, and caused rural people to be more food deficit and food insecure [12]. This disaster also posed a substantial challenge to the provision of health services as a result of damage to $>500$ health facilities [27]. Infrastructure such as bridges, electric poles, and telephone towers was washed away, and the resulting loss to the means of communication delayed emergency help from the authorities [43]. Rural households were more commonly impacted and slower to recover [12]. The flood severely affected agriculture with an estimated loss of USD 5.1 billion ( $50 \%$ of the total loss), by destroying 2.4 million hectares of soon-to-be-harvested crops (e.g. sugarcane, wheat, and rice) and livestock (mostly cows and sheep) [41, 46]. Total loss to the livestock sector alone was estimated to be USD 570 million [47]. There was no earlier warning from authorities, and the villages quickly filled up with water at night which contributed to the massive damage to crops and livestock [45].

The need for food aid was nearly ubiquitous; however, food aid from aid agencies and I/NGOs was relatively minor. There were limited efforts by the provincial agriculture department, which included the distribution of quality seeds (wheat and vegetables), extension services, feed, and veterinary care with the objective of assisting farmers to plant the next season of crops and keep livestock alive and healthy $[46,47]$. Nevertheless, many of the most affected populations, including farmers and day labourers in rural areas, were less likely to receive aid due to the lack of effective coordination between the service providers (government, I/NGOs) [12]. In addition, there was inadequate identification and/or targeting of aid to the affected families [21].

\section{Tsunami in Southeast Asia}

Southeast Asia was struck by the most devastating tsunami in modern times, caused by a 9.0 magnitude earthquake in the Indian Ocean, killing more than 250,000 people in a single day [48]. It affected more than 18 countries from Indonesia to Sri Lanka and India and left more than 1.7 million people homeless. The majority of those killed by the tsunami were poor villagers living in the most vulnerable areas along the coast of Aceh and North Sumatra in Indonesia. The coastal agriculture and fisheries sectors suffered major setbacks [49]. The estimated damage and loss to the agriculture sector in Indonesia alone was USD 225 million, while the fisheries sector suffered a loss of USD 510 million [50]. Standing rice, vegetables, plantation crops such as mangroves and tree crops, aqua farms, and livestock were severely damaged. Thousands of boats, fishing nets and gear as well as 
infrastructure, including ice plants and cold rooms, were damaged or destroyed.

The extent of aid distribution (i.e. food and temporary shelters) delivered by the aid agencies, governments and NGOs has been reported to be pathetic [51] despite billions of dollars generated by international communities in the aftermath of the tsunami. The Indonesian government executed a 5-year recovery programme to target the agricultural sector with a focus on addressing food security, the development of agribusiness, and enhancing the social welfare of farming communities; however, this programme was beset by challenges that included a lack of technical expertise in the reclamation and rehabilitation of saline-affected soils, resulting in reduced productivity and low farm income [52]. Furthermore, incomplete agricultural packages (e.g. seed, fertilizer, fence, hand tractor, and thresher) and poor quality seeds and/or delays in their distribution resulted in poor or no seed germination. Local farmers received little consideration in the disaster's aftermath since the focus was given to the construction of infrastructure rather than assistance to rural farmers who were worst affected by the tsunami [53].

\section{Gujarat earthquake}

In 2001, the Indian state of Gujarat was rattled by a devastating earthquake, which claimed over 20,000 lives [54]. The households affected by the earthquake were mainly marginal farmers and landless labourers belonging to the schedule castes and schedule tribes. The situation in rural areas was the most severe, as the earthquake happened after two consecutive years of drought [55]. The preliminary loss to the agriculture and livestock sectors was estimated to be USD 117 million (i.e. 5\% of the total assets), nearly $80 \%$ of which was in the Kutch district [56]. The reasons why damage to agriculture and livestock was relatively low included: agriculture was largely rainfed with no perennial crops in the field; there was no/little mechanization thus a low level of capital intensity; and the disaster hit at a time of day when cattle were grazing outdoors [56]. Production losses were mainly associated with delays in harvesting of the standing crops (e.g. groundnuts, pearl millet, and cotton), labour shortages, and damage to irrigation and grain storage facilities.

The relief and rehabilitation efforts were focused on people. Emergency relief food rations consisted of fortified blended food (i.e. Indiamix), wheat flour, and lentils which were provided to nearly 300,000 people for 4 months after the disaster [55]. By contrast, agriculture and livestock management received no or inadequate attention [56]. The loss of human life and livestock could have been reduced with better preparedness, a timely response and well-designed rehabilitation efforts $[55,56]$.

\section{Ethiopian disasters}

The East African nation of Ethiopia has suffered heavily from food crisis for over 50 years due to recurrent disasters such as drought, in particular the 1983-1985 famine in northern Ethiopia that led to 400,000 deaths, combined with two decades of conflicts that killed 150,000 people [57]. The combined effects of famine and internal war led to food shortages in rural areas. The situation further escalated by a weak subsistence-agriculturebased economy, depletion of assets, absence of income diversity, and a lack of alternative coping mechanisms [57]. The yields of major pulses (e.g. fava bean, lentil, field pea, chickpea, and grass pea) and cereals (e.g. barley) reduced substantially due to high temperatures and low rainfall combined with inadequate land preparation, low seed rates, inappropriate methods of sowing, and lack of weeding [58]. The heavy reliance on poor cultivars, which are susceptible to climatic extremes, pests, and diseases, also led to widespread crop failure $[58,59]$.

Over 1.5 million metric tons of emergency foods were distributed at the height of the Ethiopian famine, reaching an estimated 7.1 million people, by more than 60 organizations directly working in the region [59]. However, food aid programmes were not able to meet the demand (quantity and composition) and faced major obstacles in logistics and targeting to the vulnerable rural population [20]. The crisis was further escalated by the government's unwillingness to deal with the widespread famine, inappropriate handling of the relief materials (i.e. policy of withholding food shipment to rebel areas), and failure of the government's relocation plan (i.e. villagization) due to insufficient water, schools, medical services, and utility supply points; this caused millions to lose their lives and millions more to be displaced from rural areas [57].

\section{Lessons learned from the case studies}

There are several common themes that emerge from the above case studies. After a disaster, international aid agencies and NGOs were primarily effective at distributing immediately needed products to cities such as tents/ tarpaulins and food packages. However, often there was insufficient attention to rural agriculture after a natural disaster, as seen in Haiti [25], Nepal [60, 61], Pakistan [21], and Indonesia [52], despite agriculture being the major source of livelihoods in rural areas. Most national governments were generally ineffective at assisting rural farmers both in the short run and in the long term. For example, in the long term there were missed opportunities to re-purpose the supported urban products, such as tarpaulin materials, for agricultural use (see below). Reasons for the insufficient response appear to include: remoteness, lack of disaster preparedness, inadequate 
rescue and relief infrastructure, lack of accurate and adequate early warning and information systems, and policy and implementation shortfalls. Furthermore, the above in-kind donations (e.g. food, water, tents, and clothes) or cash provided by foreign agencies and governments were sometimes not properly utilized by national governments as seen in Nepal [61, 62]. Much food aid and money never reached the affected families, even in cities. For example, tens of thousands of tons of rice and cooking oil donated by India, Bangladesh, and China sat rotting in Kathmandu 9 months after delivery; they were finally sold on the open market by Nepali officials [61]. Issues with procurement, transport and logistical challenges for distribution happened due to complicated import and transport regulations that created roadblocks for foreign aid agencies and NGOs. Finally, the foreign I/NGOs primarily conducted the relief and rehabilitation, but these efforts sometimes weakened the state administrative capacity as seen in Haiti [13], though their intent was to assist in institution building and fight corruption. Poor coordination between foreign I/NGOs and national governments contributed to this situation. These observations underscore the need for a novel and more realistic approach to assist rural farmers after a disaster that comprehensively addresses the needs of shelter, hunger, first-aid medicines, and post-disaster labour shortages.

\section{An emergency sustainable agriculture kit-based framework for disaster relief}

The above evidence demonstrates that the interventions that primarily occur after a disaster (to cities) consist of small products (e.g. tarpaulins), likely because they are inexpensive, simple to procure and can be easily quantified for donors for impact assessment metrics. Given that the global community is somewhat effective with this strategy, we suggest that a similar strategy should be developed for rural areas, but with a focus on products that can assist farm households. Based on the above literature review, there appears to be a gap in knowledge of effective products that can target such households after a disaster. We propose that the global aid community should have a comprehensive list of such products that can be combined into packages, as well as ideas on how to re-purpose relief products provided to urban areas. We further propose that there should be strategies to permit rural distribution of these products by local governments or CBOs, or NGOs in partnership with local governments, rather than only relying on national governments or foreign NGOs. We will refer to this strategy as the emergency sustainable agriculture kit (eSAK) framework for disaster relief.

\section{Criteria for effective product-based interventions for rural disaster relief}

Within eSAK, there are several criteria for the smart selection of products that can effectively target smallholder agricultural households after a natural disaster.

\section{Needed}

An excess of unnecessary donations and/or inadequate essential donations are commonly observed after a disaster $[48,63]$. Therefore, materials that are distributed to rural households should be need-based and relevant to the local context.

\section{Reusable}

Ideally products should be multi-purpose to provide flexibility since every household will have different needs (e.g. not necessarily a tent but rolls of plastic, as a tent is appropriate in cities $[15,64]$ but not necessary in rural areas where farmers have access to wood to build poles).

\section{Inexpensive}

The loss of livelihoods and property caused by disasters significantly reduces the purchasing capacity of rural farmers in developing countries [12, 65]. An individual product may be needed in large numbers, so it must be low cost. If a product is inexpensive, farmers can also afford to purchase it by themselves.

\section{Labour efficient}

Labour shortages occur after a disaster due to the loss of human life and livestock, injury, and a change in priority towards rebuilding efforts rather than farming $[4,14$, 60]. As a result, ideally a post-disaster product should be labour efficient and possibly replace lost labour after a disaster.

\section{Compact and light weight}

Distribution of logistics is a major problem in rural areas, usually made worse after a disaster [32, 66]. Rural hills and mountains in developing countries are places where relief efforts are especially affected by high transaction costs associated with remoteness and poor infrastructure $[4,67]$. In such areas, transportation during emergencies is often limited to dropping supplies by helicopter [68]. In addition, people in developing countries carry materials on their backs $[4,12,65]$; therefore, relief products are needed that are easy to transport into rural areas.

\section{Available/procurable on a large scale}

After a disaster, relief materials are required in large numbers. Ideal products are those where the materials can be purchased locally (i.e. rural products), but after a 
Table 2 Ten high-impact agricultural interventions after a disaster, their use(s) and cost [14]

\begin{tabular}{|c|c|c|}
\hline Products & Purpose & $\begin{array}{l}\text { Cost/fam- } \\
\text { ily (USD) }\end{array}$ \\
\hline \multicolumn{3}{|l|}{ Emergency needs (immediate) } \\
\hline Rolls of agricultural-grade plastic & $\begin{array}{l}\text { Inexpensive shelter for humans, cattle and seeds, for later re-purposing to construct a } \\
\text { greenhouse or use as groundcover to suppress weeds, conserve water and soil }\end{array}$ & $\$ 15.00$ \\
\hline Low-oxygen grain storage bag & To protect seeds from monsoon rains and prevent losses due to moulds and insects & $\$ 1.00$ \\
\hline Waterproof gardening gloves & To clear debris and later re-purpose for farm work to reduce female hardship & $\$ 0.50$ \\
\hline Foldable military shovel & To clear debris and can be re-purposed for agricultural needs & $\$ 3.00$ \\
\hline First-aid kit & $\begin{array}{l}\text { Frontline care, and to reduce infections which would otherwise cause declines in farm } \\
\text { labour }\end{array}$ & $\$ 2.00$ \\
\hline \multicolumn{3}{|l|}{ Medium-term needs (1-4 months) } \\
\hline $\begin{array}{l}\text { Seed package of rapid maturing grains/ } \\
\text { starch crops }\end{array}$ & To allow farmers to produce calories rapidly and prevent consumption of sowing seeds & $\$ 1.75$ \\
\hline $\begin{array}{l}\text { Seed package of rapid maturing beans } \\
\text { (legumes) }\end{array}$ & To allow farmers to produce protein rapidly and prevent consumption of sowing seeds & $\$ 1.50$ \\
\hline $\begin{array}{l}\text { Seed package of rapid maturing veg- } \\
\text { etables }\end{array}$ & $\begin{array}{l}\text { To allow farmers to produce vitamins and minerals (micronutrients) rapidly, especially } \\
\text { required for pregnant women and children }\end{array}$ & $\$ 1.50$ \\
\hline Bag of nitrogen fertilizer $(5 \mathrm{~kg})$ & $\begin{array}{l}\text { An inexpensive method to promote an immediate increase in food production within } \\
3 \text { months }\end{array}$ & $\$ 2.00$ \\
\hline Low-cost tool package & To mitigate losses in farm labour caused by death/injury to humans and livestock & $\$ 10.00$ \\
\hline Total kit cost for a household of 5 people & The entire kit is not needed; even a single one of the above products will be beneficial & $\$ 40.00$ \\
\hline
\end{tabular}

disaster, there are local price spikes of products in high demand [11]. Hence, products must be selected that can be procured and shipped in bulk from international sources rapidly. In today's era, the Internet provides a global marketplace, such as the website, Alibaba.com [4, $14]$.

\section{Simple and amenable to illustration}

In rural areas, where illiteracy prevents communication with recipients on how to use relief products beyond tents and direct food [14], it is important for a relief product to be simple to use and for its correct usage to be explainable by an accompanying graphical illustration [69]. The illustration, along with captions in the local language, will ensure that beneficiaries, including illiterate women, understand and make best use of each product.

\section{Specific post-disaster product recommendations}

Based on the above criteria, we propose that the following products may be useful in supporting disaster-affected smallholder farm families in developing countries in their efforts to maintain livelihoods. A list of products, their uses and associated costs are summarized (Table 2). All of these products meet all or most of the selection criteria.

\section{Rolls of agricultural-grade plastics}

Natural disasters can devastate structures (home, buildings, etc.) in both cities and rural areas, as seen in Haiti [40, 64, 70], Indonesia [48], and Nepal [14, 37].
Traditionally, tarpaulin and tents are provided to cities for shelter. Here, we propose that tarpaulin or agricultural-grade plastics should be provided to rural areas for shelter (in rural areas, as noted above, people can make their own tents using local wood as poles), but also for animal shelters (Fig. 1a), to replace collapsed roofs, and to cover food grains and long-term seed stocks. The side or roof of a tent can be modified for rainwater harvesting when water is scarce. Rather than adding to pollution, the tarpaulin/plastic distributed to rural areas but especially urban areas can later be re-purposed as plastic greenhouses (tunnels) to protect high-value vegetables against insects and extreme temperatures (Fig. 1b). Alternatively, it may be used as a groundcover mulch to suppress weeds and conserve soil and water (Fig. 1c). Such efforts could be enabled by distributing these products with graphical lessons. Based on the literature, it does not appear that there have been coordinated efforts to recycle tarpaulin after disasters.

\section{Low-oxygen grain/seed storage bags}

The monsoon rains were shown to destroy seeds after the earthquake in Nepal [37, 60] and Haiti [2] and after the floods in Pakistan [21]. When structures are damaged and there are seasonal rains, precious seeds that are stored in homes or mud granaries may become wet, causing loss to livelihoods and generations of associated indigenous knowledge [2, 14]. Such damage further weakens/destroys the local seed supply mechanism [24] making farmers vulnerable to seed crisis in the long term 
a

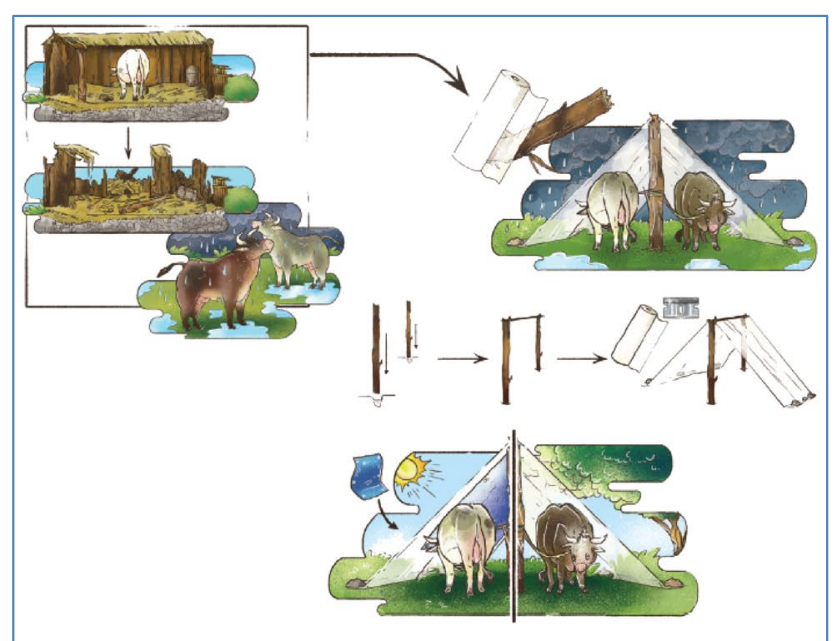

b

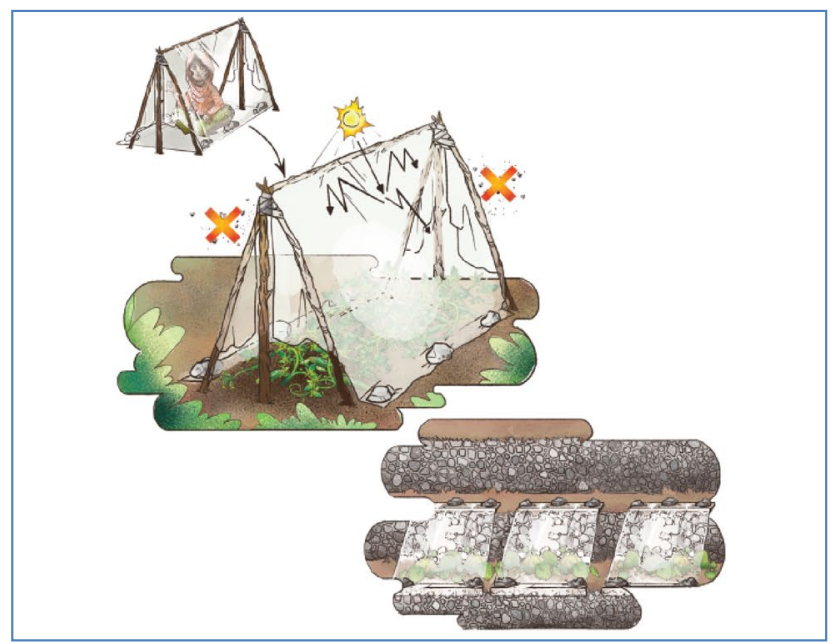

C

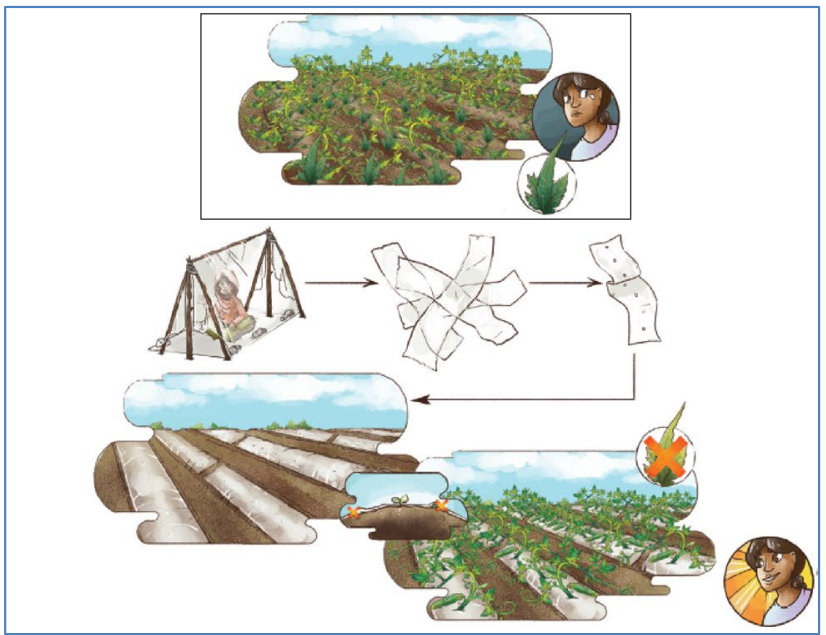

Fig. 1 Graphical illustration of post-disaster use and re-use of agricultural-grade plastic or tarpaulin: a Tent for livestock shelter; b Re-purposing into a plastic tunnel (greenhouse) to protect high-value vegetables against insects and extreme temperatures; $\mathbf{c}$ Re-purposing into agricultural mulch to suppress weeds (and conserve water and soil). In panels $\mathbf{a}$ and $\mathbf{c}$, the boxed image in the upper left/top represents the challenge after a disaster. (Images courtesy of Lisa Smith, University of Guelph, can be reused under the Creative Commons BY licence) 
[23]. To protect precious seeds, inexpensive low-oxygen grain storage bags (also called hermetic storage bags, Fig. 2) that are made from soft, foldable plastic (similar to a garbage/grocery bag) can be distributed to the affected areas (e.g. GrainPro bag and Purdue Improved Cowpea Storage bag). Aside from waterproofing, each bag consists of multiple layers of thick plastic that allows oxygen to flow out, but not back in, thus preventing fungi and insects from damaging stored grain [14], which is problematic under high moisture.

\section{Waterproof gardening gloves and shovel}

In developing countries, post-disaster debris cleanup and building are often undertaken manually, causing hardship to men, women, children, and the elderly who are already under stress after a disaster [27, 39]. Rural farmers mostly use their bare hands while removing brick, stone, and mud debris, which becomes even more difficult in the rain (e.g. monsoon) [14]. Debris removal may cause injury, which may lead to further infection. Simple, waterresistant gardening gloves (Fig. 3a) and a multi-purpose military-grade shovel (Fig. 3b) would be helpful to clear debris and can then be re-purposed to reduce hardship in agriculture $[14,60]$. Specifically, gardening gloves can be used to collect wood, remove weeds, work with a plough, etc. A military-grade shovel with a serrated edge can be used both as a shovel and as a wood saw to assist with cooking fuelwood processing, pruning, and digging holes for poles during tent construction. Such shovels are inexpensive, lightweight, fold to be compact for transport, and can be procured rapidly on a large scale.

\section{Inexpensive agricultural tool packages}

Livestock are the only source of labour and fertilizers (manure) for many smallholder farmers. A shortage of labour due to death and injury of humans and livestock is frequently observed after disasters, such as after the super cyclone in Orissa, India [71]. In addition, labour is diverted to rebuilding efforts as seen in Haiti and Nepal $[13,60]$. Furthermore, existing farm tools may be lost due to building collapse, as seen in Nepal [60]. For these reasons, it is essential to support an inexpensive set of agricultural tools/equipment to reduce labour. For example, if a male member of the household is injured or dies, there may be an inability to plough the land using livestock as there are cultural taboos as well as physical constraints against women undertaking this activity. A simple, lightweight seed planter (e.g. jab planter, adjustable for various seed sizes to permit planting of grains and legumes; Fig. 4), and a set of local digging tools (e.g. spade or hoe, rake, sickle, along with the above military shovel) may serve to mitigate losses in farm labour $[4,14]$.

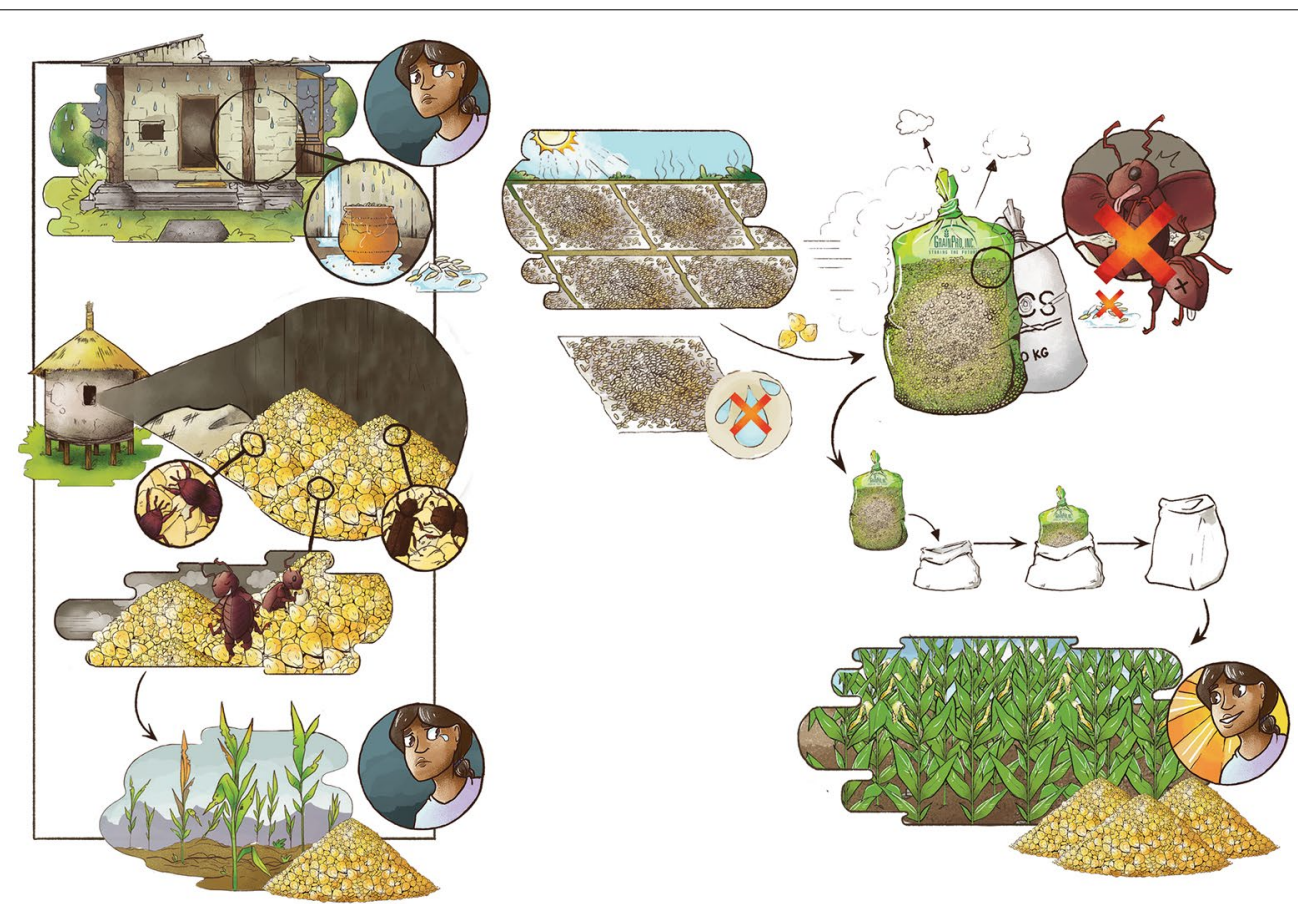

Fig. 2 Graphical illustration of the use of low-oxygen grain storage bags to suppress fungal moulds and insects. The boxed image in the left represents the challenge after a disaster. (Images courtesy of Lisa Smith, University of Guelph, can be reused under the Creative Commons BY licence) 
a

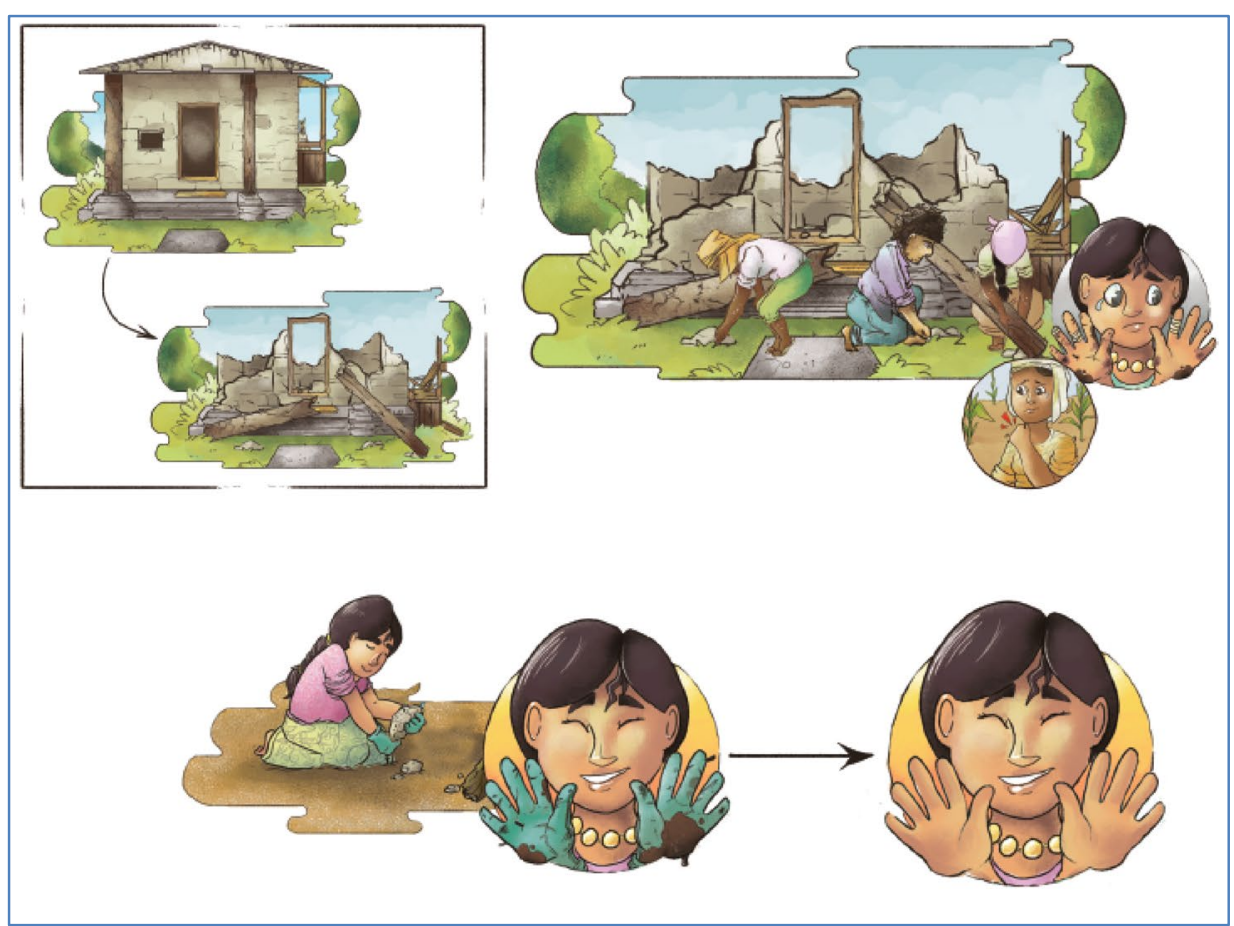

b

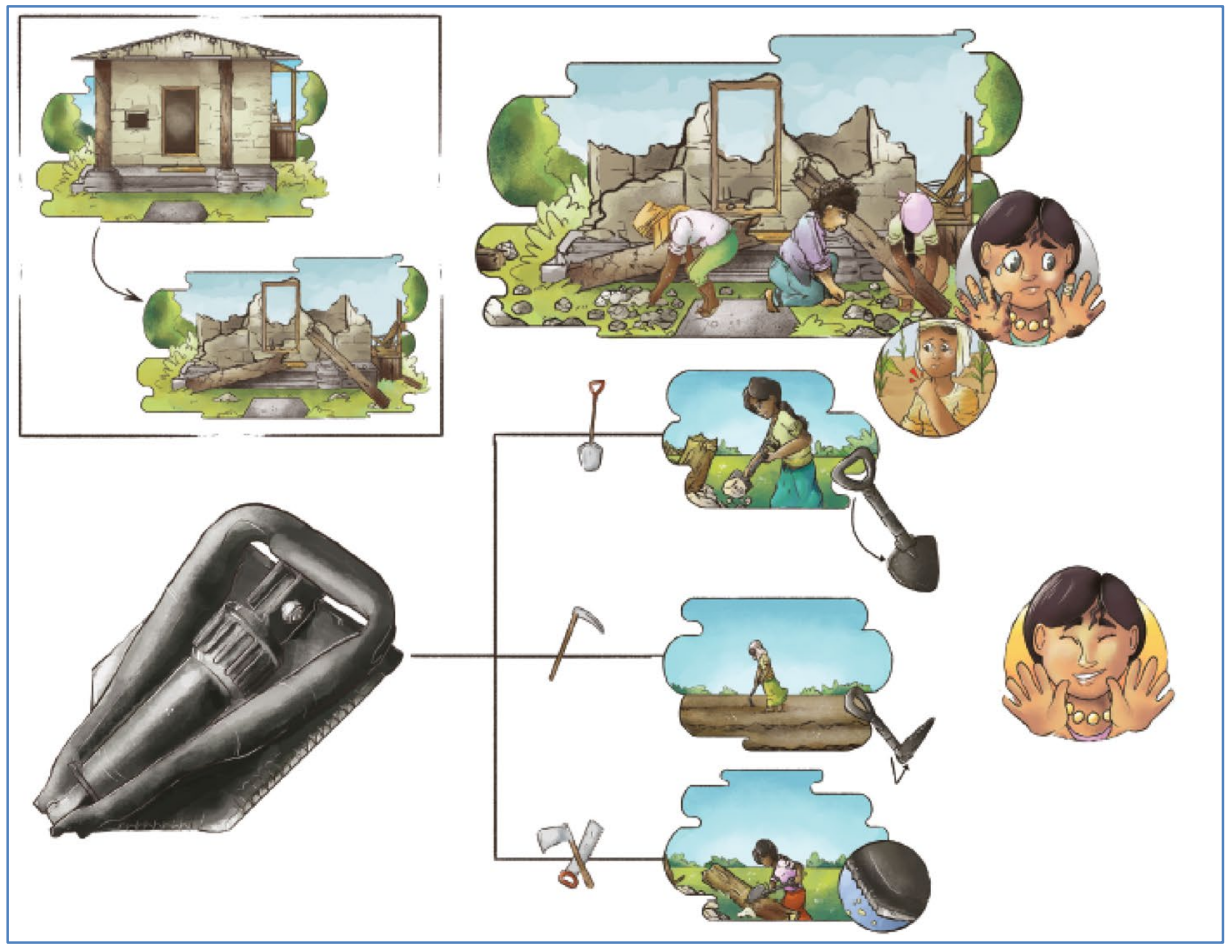

Fig. 3 Graphical illustration of the use of $\mathbf{a}$ hand gloves and a $\mathbf{b}$ multi-purpose military shovel. The boxed image in the upper left represents the challenge after a disaster. In each case, the use of the product for disaster cleanup is shown, followed by how it may be re-purposed for agricultural needs. (Images courtesy of Lisa Smith, University of Guelph, can be reused under the Creative Commons BY licence)

Seeds of early maturing crop varieties along with fertilizers Farmers may lose all seeds if seeds stored inside a house collapses, or if the seeds become wet $[1,2]$. In such situations, appropriate and timely distribution of seed can bring very significant improvements to agricultural production and food security [23]. Seeds of 


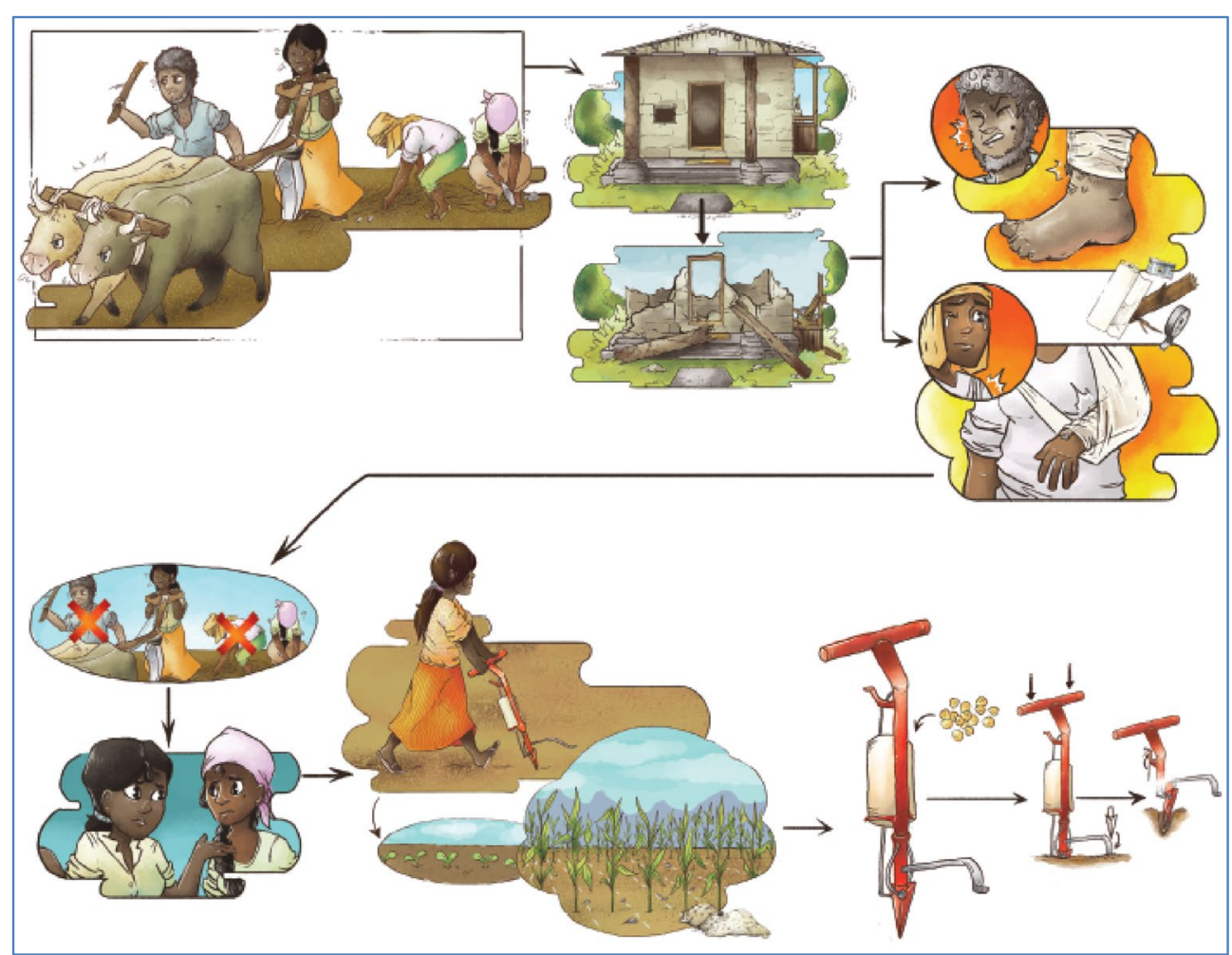

Fig. 4 Graphical illustration of the use of a jab drill planter for sowing seeds to save labour after a disaster. The boxed image at the top represents the challenge after a disaster. (Images courtesy of Lisa Smith, University of Guelph, can be re used under the Creative Commons BY licence)

early-to-mature varieties of cereals, legumes, and vegetables can be provided to farmers for planting, to ensure they begin to produce food for themselves as early as possible to prevent hunger, and as a source of calories, protein, and critical micronutrients (vitamins and minerals) [14]. Seed support further prevents farmers from eating critical planting seeds including their indigenous varieties cultivated over generations. Providing seeds to small-scale farmers in advance of the major planting season can translate to 6 months of food supply and income [42, 46]. In Rwanda, after the genocide and war of 1994, agricultural rebuilding efforts largely comprised of highquality seeds, crop and variety development and conservation, and rebuilding human resource capacity as well as basic scientific facilities [72]. Unfortunately, poorly designed seed aid can actually undermine local resilience by providing untested new varieties, narrowing crop diversity, and adversely impacting local seed enterprises $[2,23]$. Therefore, care should be taken while choosing the crop varieties; they should be early maturing, diverse, and compatible with the growing season and location [73-75].

Along with the early maturing crops, a small bag of nitrogen fertilizer (5-10 kg per household) is likely to raise crop yields rapidly, which is a simple intervention guaranteed to have a positive impact $[4,14]$. One of the major factors contributing to chronic poverty and malnutrition in Haiti after the earthquake was no or little attention given to improve soil fertility [25].

There may be circumstances when seed is not required. Contrary to the above reports, there is limited literature which concludes that seed systems were relatively resilient to political and civil conflict (Zimbabwe and South Sudan), earthquake (Haiti), and drought (Kenya), at least in terms of meeting farmer's planting needs for the upcoming season $[2,24]$. The authors note that factors that helped local seed systems to be resilient included: social networks (e.g. farmer-to-farmer barter exchange of seeds), recent bumper harvests, informal seed and grain markets, and local agro-dealers. Combined, these channels were claimed to have provided $>80 \%$ of total seed requirements for key crops (e.g. maize, groundnut, sorghum) in Zimbabwe, South Sudan (sorghum, maize, groundnut), Haiti (bean, maize, pigeonpea), and Kenya (maize, greengram, cowpea) [2].

\section{First-aid kit}

People in both cities and rural areas often suffer illness and injuries during a disaster [27] including severe mental health problems such as post-traumatic stress 
$[10,26]$. Though a subset of these medical issues cannot be treated at the household level [27] including fractures of the lower limbs or other bones [54], health officials have observed that a large fraction of injuries (65\%) after natural disasters consist of open wounds/ superficial lacerations [76]; the latter frequently leads to infections because of poor access to medical supplies which can become damaged by a disaster, and furthermore, rural populations are often far from medical facilities. A simple first-aid kit including large and small bandages, topical antibiotics, topical alcohol cleaning pads, Dettol, anti-diarrhoea supplements, etc., along with graphical lessons on their correct usage, should prevent infections, especially to small wounds suffered during a disaster or during debris clearing. A first-aid kit does not replace access to medical care, but it is an inexpensive frontline intervention to help farmers.

\section{Temporary food support}

Food shortages are often seen in disaster hit areas [2, 20, 57]. The situation is made worse when a disaster happens in food insecure rural areas of developing countries [5, 6]. In addition, as already noted, consumption of planting materials may lead to a secondary disaster $[13,14]$. Therefore, distribution of food supplements along with a set of basic household supplies (e.g. cooking and eating utensils, blankets, and inexpensive sleeping mats) should be a part of immediate relief efforts after an emergency $[14,60]$. An ideal food package would consist of precooked foods for the initial day(s) after a disaster (e.g. beaten or puffed rice, noodles, and biscuits) [14], as well as staple uncooked foods (e.g. wheat flour, rice, and corn) for the subsequent week(s). Foods should be culturally appropriate, nutritious in calories, protein and micronutrients including iron, zinc and folic acid for pregnant women and children, and fast cooking (e.g. small grains such as rice, lentils). Salt should also be distributed (which also allows faster cooking at higher altitudes). Long-term food support can be facilitated through food-for-work [77] or cash-for-work [65] programmes that also help to minimize post-crisis violence associated with food shortages. Indonesia observed very positive results from a cash-for-work programme for returning displaced populations in Aceh province after the tsunami [65]. Also in the longer term, families who lost their livestock can be supported with small livestock such as goats and piglets to maximize manure and urine collection as sources of organic fertilizer, or a brood of chickens to supply daily eggs, and possibly simple fishing supplies.

\section{Post-disaster product distribution and logistics}

Delays in delivery or relief can cost lives. Therefore, efficiency in logistics is a key success factor in a disaster response operation [31]. The basic mission of distribution or supply chain management involves the delivery of products and/or services to the needy, whose immediateor long-term survival can depend on its efficient execution. As already noted, distribution is a major challenge to remote, rural areas after a disaster. Internationally sponsored NGOs have been criticized for being ineffective in channelling resources, as seen in Haiti [13] and Southeast Asia [30]. The reasons for their ineffectiveness have included: the donation of unnecessary goods, an uncoordinated flow of donations, a lack of efficient communication systems, unprepared staff, a poor decisionmaking process, a lack of cooperation among the main actors involved, and lack of central coordination of the operation [31].

Distribution channels can be improved when humanitarian activities are led by one of the actors at the scene who understands business practices and supply chain management [78]. Products are more likely to reach affected families when there is coordination with the local government and grassroots organizations (CBOs) who can identify priority/target areas and their needs in order to effectively spend foreign aid money on procurement of needed products [14, 32, 78]. Such coordination can also lead to effective distribution approaches. In China and Nepal, for example, the government give some support to help people who do not have enough funds to repair or rebuild their homes through a disaster relief fund [32, 34]. This kind of support can be channelled through a rural credit cooperative system involving local governments and private financial institutions which help national government to strengthen supervision, management, and allocation of relief funds to people in need. As an alternative, the private sector can directly support rebuilding of the agriculture sector through a package of support intended to promote local agriculture.

It is noteworthy that alcohol, cigarettes, and snackfoods are available for purchase in even the most remote villages of the world, demonstrating that effective distribution networks to rural areas already pre-exist. We propose piggybacking onto these distribution networks as a good strategy to scale up relief products to rural areas after a disaster [14]. Such a strategy appears to have been untapped in previous disasters. For example, in Haiti, thousands of women known as the Madame Saras and revendeuses comprise an informal private sector distribution network between cities and farms [79]. 


\section{Conclusions}

Here, we have reviewed recent natural disasters in developing countries. The literature demonstrates that insufficient attention is often paid to rural agriculture after a disaster despite its importance. After a disaster, the international community and NGOs have been most effective at distributing products such as tents/tarpaulin and food packages but primarily to cities. Recognizing the success of a product-based approach, here we have proposed an eSAK framework for disaster relief in which we suggest a list of products and graphical lessons to help farmers after a disaster based on a number of criteria. As distribution of products to rural areas is a challenge, especially after a natural disaster, we have also proposed a novel distribution strategy, involving pre-existing cigarette/alco$\mathrm{hol} /$ snackfood distributors. Smart selection of products appropriate for the local context, as well as procurement and distribution, must involve partnerships led by local stakeholders along with dedicated funding for rural peoples from governments and international aid agencies.

This review further indicated that coordination is one of the common factors that is associated with failed and/ or inefficient post-disaster relief operations. In order to improve coordination after an emergency among local and national governments, non-governmental organizations, the private sector and other stakeholders, the cluster system created by the United Nations Office for the Coordination of Humanitarian Affairs (UN-OHCA) may be appropriate [80]. Clusters are groups of humanitarian organizations (UN and non-UN) that are created to enable a response to be coherent and complementary, identifying ways to work together for better collective results. Clusters provide a clear point of contact and are accountable for adequate need-based, rather than capacity-driven, humanitarian assistance by creating partnerships between international humanitarian organizations, national and local authorities, and civil society. This approach has been repeatedly cited as having "benefits that outweigh the costs", and although it has been criticized for a number of challenges, it is currently considered the most appropriate structure for relief coordination [81]. To conclude, we hope that this paper will stimulate more dialogue about the gaps that exist in helping rural farmers after a disaster.

\footnotetext{
Abbreviations

CBO: community-based organizations; eSAK: emergency sustainable agriculture kit; FAO: Food and Agriculture Organization (of the United Nations); GDP: gross domestic product; I/NGO: international/non-governmental organization; MoAD: Ministry of Agricultural Development (Nepal); WFP: World Food Programme.

\section{Authors' contributions}

TC and MNR collaboratively designed the study, performed the literature review and analysis, and wrote and edited the manuscript. Both authors read and approved the final manuscript.
}

\section{Acknowledgements}

We thank Lisa Smith (University of Guelph) for creating the graphical illustrations. We thank Kamal Khadka (University of Guelph) for his helpful ideas and suggestions. We thank members of the Raizada Lab (University of Guelph) and researchers of SAKNepal, a project funded by the Canadian International Food Security Research Fund (CIFSRF), jointly sponsored by the International Development Research Centre (IDRC, Ottawa) and Global Affairs Canada (GAC).

\section{Competing interests}

Neither the authors nor the University of Guelph received payment or services from a third party for any aspect of the submitted work. No financial relationships exist with any entities that could be perceived to influence the submitted work. There are no patents or copyrights relevant to this work. There are no relationships or activities to disclose that could be perceived to have influence the submitted work.

\section{Ethics approval and consent to participate}

This study does not involve any human, animal or plant subjects, and materials. Both authors have read and agreed to its content and that the manuscript conforms to the journal's policies.

\section{Funding}

This study was supported by a grant to MNR from the Canadian International Food Security Research Fund (CIFSRF), jointly sponsored by the International Development Research Centre (IDRC, Ottawa) and Global Affairs Canada (GAC). The funding body had no role in the design of the study or the collection, analysis, or interpretation of the data.

\section{Publisher's Note}

Springer Nature remains neutral with regard to jurisdictional claims in published maps and institutional affiliations.

Received: 25 August 2016 Accepted: 2 April 2017

Published online: 10 May 2017

\section{References}

1. Sperling L. When disaster strikes: a guide to assessing seed system security. Cali: International Center for Tropical Agriculture; 2008.

2. McGuire S, Sperling L. Making seed systems more resilient to stress. Glob Environ Change. 2013;23:644-53.

3. Wiggins S, Proctor S. How special are rural areas? The economic implications of location for rural development. Dev Policy Rev. 2001;19:427-36.

4. Chapagain T, Raizada MN. Agronomic challenges and opportunities for smallholder terrace agriculture in developing countries. Front Plant Sci. 2017:8:331. doi:10.3389/fpls.2017.00331.

5. FAO [Food and Agriculture Organization]. From agriculture education to education for rural development and food security: all for education and food for all. In: From production agriculture to rural development: challenges for higher education in the new millennium. 5th European conference on higher agricultural education, University of Plymouth; 2000 .

6. FAO [Food and Agriculture Organization]. The state of food insecurity in the world. Rome: Food and Agriculture Organization of the United Nations; 2014.

7. Atchoarena D, Gasperini L. Education for rural development: towards new policy responses. A joint study conducted by FAO and UNESCO. Rome: FAO/UNESCO; 2003. p. 35-69.

8. Chapagain T, Gurung GB. Effects of integrated plant nutrition management (IPNM) practices on the sustainability of maize based hill farming systems in Nepal. J Agric Sci. 2010;2(3):1-7. doi:10.5539/jas.v2n3p26.

9. Sabates-Wheeler R, Devereux S, Mitchell T, Tanner T, Davies M, Leavy J. Rural disaster risk: poverty interface. Brighton: Institute of Development Studies, University of Sussex; 2008. p. 3-19.

10. Pynoos RS, Goenjian A, Tashjian M, Karakashian M, Manjikian R, Manoukian G, Steinberg AM, Fairbanks LA. Post-traumatic stress reaction in children after the 1988 Armenian earthquake. Br J Psychiatry. 1993;163:239-47. 
11. Kirsch TD, Wadhwani C, Sauer L, Doocy S, Catlett C. Impact of the 2010 Pakistan floods on rural and urban populations at six months. PLOS Curr Disasters. 2012;1. doi:10.1371/4fdfb212d2432

12. Ashraf S, Iftikhar M, Shahbaz B, Ali Khan G, Luqman M. Impacts of flood on livelihoods and food security of rural communities: a case study of southern Punjab, Pakistan. Pak J Agric Sci. 2013;50:751-8.

13. Zanotti L. Cacophonies of aid, failed state building and NGOs in Haiti: setting the stage for disaster, envisioning the future. Third World Q. 2010;31:755-71.

14. Raizada MN, Chapagain T, Khadka K. Top 10 inexpensive interventions to help farmers in Nepal after the 2015 earthquake. A brief report for the Canadian department of foreign affairs, trade and development (DFATD). Guelph: University of Guelph; 2015.

15. Fiedrich F, Gehbauer F, Ricker U. Optimized resource allocation for emergency response after earthquake disasters. Saf Sci. 2000;35:41-57.

16. USGS [United States Geological Survey]. Post-earthquake USG Haiti strategy toward renewal and economic opportunity. 2015. http://www.state. gov/documents/organization/156448.pdf. Accessed 12 May 2015.

17. FAOSTAT. Global population dynamics. 2015. http://faostat3.fao.org/ browse/O/*/E. Accessed 12 May 2015.

18. World Bank. Agriculture for development. World development report 2008. Washington, DC: World Bank; 2007

19. WFP [World Food Programme]. Who are the hungry? 2015. https://www. wfp.org/hunger/who-are. Accessed 12 May 2015

20. Kaluski DN, Ophir E, Amede T. Food security and nutrition: the Ethiopian case for action. Public Health Nutr. 2002;5:373-81.

21. Doocy S, Leidman E, Aung T, Kirsch T. Household economic and food security after the 2010 Pakistan floods. Food Nutr Bull. 2013;34:95-103.

22. Hossain SMM, Talat M, Boyd E, Chowdhury SR, Soofi SB, Hussain I, Ahmed I, Salam RA, Bhutta ZA. Evaluation of nutrition surveys in flood-affected areas of Pakistan: seeing the unseen! IDS Bull. 2013;44:10-20.

23. Longley C, Dominguez C, Saide MA, Leonardo WJ. Do farmers need relief seeds? A methodology for assessing seed systems. Disasters. 2002;26:343-55

24. Byrne KG, March J, McGuire S, Meissner L, Sperling L. The role of evidence in humanitarian assessment: the seed system security assessment and the emergency market mapping and analysis. Disasters. 2013;37:S83-104

25. Bargout RN, Raizada MN. Soil nutrient management in Haiti, pre-Columbus to the present day: lessons for future agricultural interventions. Agric Food Secur. 2013;2:11

26. Chadda RK, Malhotra A, Kaw N, Singh J, Sethi H. Mental health problems following the 2005 earthquake in Kashmir: findings of community-run clinics. Prehosp Disaster Med. 2007;22:541-5.

27. Shabir O. A summary case report on the health impacts and response to the Pakistan floods of 2010. PLOS Curr Disasters. 2013;1. doi:10.1371/currents.dis.cc7bd532ce252c1b740c39a2a827993f

28. Lu X, Bengtsson L, Holme P. Predictability of population displacement after the 2010 Haiti earthquake. PNAS. 2012;109:11576-81.

29. Mueller V, Gray C, Kosec K. Heat stress increases long-term human migration in rural Pakistan. Nat Clim Change. 2014;4:182-5.

30. Telford J, Cosgrave J. The international humanitarian system and the 2004 Indian ocean earthquake and tsunamis. Disasters. 2007;31:1-28.

31. Da Costa SRA, Bandeira RAM, Mello LCBB, Campos VBG. Humanitarian supply chain: an analysis of response operations to natural disasters. Eur J Transp Infrastruct Res. 2014;14:290-310.

32. Yang Y, Yang ND, Wei SX, Qian JB, Ji SG. Optimization and selection of distribution channel of disaster relief fund for peasants to rebuild houses in Huaxian. In: Wang Y, Issa RR, Zhu Y, Shen Q, editors. Proceedings of 2006 international conference on construction and real estate management vol 1 and 2: collaboration and development in construction and real estate, Orlando, FL. Beijing: China Architecture and Building Press; 2006. p. 521-4.

33. Manandhar P. Food security: key terms and debate. In: Upreti BR, Sharma SR, Paudel SB, editors. Food security in post conflict Nepal: challenges and opportunities. Kathmandu: Department of Development Studies, School of Arts, Kathmandu University and Nepal Centre for Contemporary Research (NCCR); 2014. p. 19-46.

34. OXFAM. The Nepal earthquake six months on: What needs to happen now? Media briefing 25 October 2015. https://www.oxfam.org.nz/sites/ default/files/reports/mb-nepal-earthquake-six-months-251015-en.pdf. Accessed 20 July 2016.
35. GoN/NPC. Nepal earthquake 2015: Post disaster needs assessment. Vol A: key findings. Kathmandu: Government of Nepal, National Planning Commission; 2015. p. 21-2.

36. MoAD [Ministry of Agricultural Development]. Country investment plan: Nepal agriculture and food security. Kathmandu: MoAD; 2010.

37. Dey S. A devastating disaster: a case study of Nepal earthquake and its impact on human beings. IOSR J Hum Soc Sci. 2015;20:28-34.

38. FAO. One year after the earthquakes. 2016. http://www.fao.org/emergencies/crisis/nepal-earthquakes/en/. Accessed 20 July 2016.

39. Risler E, Kintzle S, Nackerud L. Haiti and the earthquake: examining the experience of psychological stress and trauma. Res Soc Work Pract. 2015;25:251-6

40. Haitian Conference. Action plan for national recovery and development of Haiti, Government of the Republic of Haiti. 2010. http://haiticonference.org/Haiti_Action_Plan_ENG.pdf. Accessed 27 June 2016.

41. UN. Agriculture and disaster risk. 2015. http://www.wcdrr.org/documents/wcdrr/prepcom1/UN/ATTFONWO.pdf. Accessed 20 July 2016.

42. FAO. FAO and emergencies, from prevention to building back better: Haiti earthquake 2010. http://www.fao.org/emergencies/crisis/haitiearthquake-2010/en/. Accessed 20 July 2016.

43. Dupuy A. Disaster capitalism to the rescue: the international community and Haiti after the earthquake. North American Congress in Latin America (NACLA) report on the Americas. New York: NACLA. 2010.

44. Kolbe AR, Hutson RA, Shannon H, Trzcinski E, Miles B, Levitz N, Puccio M, James L, Noel JR, Muggah R. Mortality, crime and access to basic needs before and after the Haiti earthquake: a random survey of Port-au-Prince households. Med Confl Surviv. 2010;26:281-97.

45. Zulqarnain Z. Economic impact of floods on small scale farmers of Pakistan: a case study from the district Nowshera, Khyber Pukhtunkhwa province. Uppsala: Department of Urban and Rural Development; 2013. p. 7-37.

46. FAO. FAO and emergencies, from prevention to building back better: floods. 2015. http://www.fao.org/emergencies/emergency-types/floods/ en/. Accessed 20 July 2016.

47. ADB. Pakistan floods 2010: preliminary damage and needs assessment. 2015. http://www.adb.org/sites/default/files/linked-documents/44372 01-pak-oth-02.pdf. Accessed 20 July 2016.

48. Hyndman J. Duel disasters: humanitarian aid after the 2004 tsunami. Colorado: Lynne Rienner Publishers; 2011. ISBN 978-1-56549-336-0.

49. FAO. FAO and emergencies, from prevention to building back better: tsunami. 2015. http://www.fao.org/emergencies/emergency-types/tsunami/en/. Accessed 20 July 2016.

50. BAPPENAS. Indonesia: preliminary damage and loss assessment, the December 26, 2004 natural disaster. 2015. http://www.unep.org/tsunami/ reports/damage_assessment.pdf. Accessed 20 July 2016.

51. Ali MM. Tsunami's colossal human toll, and its social, economic and political ramifications. Wash Rep Middle East Aff. 2005;24:36-7.

52. FAO. Report of the regional workshop on rehabilitation of agriculture in tsunami affected areas: one and a half year later, Bangkok. 29-30 June 2006.

53. Wai-Poi M. Financing the millennium development goals: the millennium project report. J Int Aff. 2005;58:285-90.

54. Phalkey R, Reinhardt JD, Marx M. Injury epidemiology after the 2001 Gujarat earthquake in India: a retrospective analysis of injuries treated at a rural hospital in the Kutch district immediately after the disaster. Glob Health Action. 2011:4:7196.

55. UN Disaster Management Team. UN system response to the Gujarat earthquake immediate needs and action plan. 2015. http://reliefweb.int/ report/india/un-system-response-gujarat-earthquake-immediate-needsand-action-plan. Accessed 21 July 2016.

56. The World Bank/ADB. Gujarat earthquake recovery program: assessment report. 2015. http://www.preventionweb.net/files/2608_fullreport.pdf. Accessed 20 July 2016.

57. de Waal A. Evil days: thirty years of war and famine in Ethiopia. New York: Human Rights Watch; 1991. ISBN 1-56432-038-3.

58. El-Beltagy A. Ethiopia: a future without famine. 2015. http://www.worldbank.org/html/cgiar/newsletter/Oct95/3ethio.htm. Accessed 20 July 2016.

59. USAID/Addis Ababa. Ethiopia drought/famine: final disaster report. 1985/1986. http://pdf.usaid.gov/pdf_docs/PNABG233.pdf. Accessed 20 July 2016. 
60. Chapagain T. Save the soil. 2015. http://kathmandupost.ekantipur.com/ printedition/news/2015-06-01/save-the-soil.html. Accessed 28 June 2016.

61. Symmes P. A year after the quake, Nepal is still a mess. 2016. http://www. outsideonline.com/2086666/aftershock. Accessed 14 July 2016.

62. Tayler A. Nepal's earthquakes: one year later. 2016. http://www.theatlantic.com/photo/2016/04/nepals-earthquakes-one-year-later/479772. Accessed 27 June 2016.

63. Keys A, Masterman-Smith $\mathrm{H}$, Cottle D. The political economy of a natural disaster: the boxing day tsunami 2004. Antipode. 2006;38:195-204.

64. Versluis A. Formal and informal material aid following the 2010 Hait earthquake as reported by camp dwellers. Disasters. 2014;38:S94-109.

65. Doocy S, Gabriel M, Collins S, Robinson C, Stevenson P. Implementing cash for work programmes in post-tsunami Aceh: experiences and lessons learned. Disasters. 2006;30:277-96.

66. Mulligan M, Nadarajah Y. Rebuilding community in the wake of disaster: lessons from the recovery from the 2004 tsunami in Sri Lanka and India. Community Dev J. 2012;47:353-68.

67. Ashley C, Maxwell S. Rethinking rural development. Dev Policy Rev. 2001;19:365-425.

68. Jordan D. Countering insurgency from the air: the postwar lessons. In: Benbow T, Thornton R, editors. Dimensions of counter insurgency: applying experience to practice. New York: Routledge (Taylor \& Francis); 2013. p. 90-105. ISBN 13: 978-0-415-45037-9, 10: 0-415-45037-3.

69. Raizada MN, Smith L. A picture book of best practices for subsistence farmers: South Asian edition. eBook, University of Guelph Sustainable Agriculture Kit (SAK) Project, Guelph. 2016. www.saknepal.org.

70. Margesson R, Taft-Morales M. Haiti earthquake: Crisis and response. Washington, DC: Congressional Research Service; 2010.

71. Ganguli D, Chander M. Impact of natural disasters on livestock farmers: the case of Orissa supercyclone of 1999 in India. Indian J Anim Sci. 2007;77(6):504-8.
72. Buruchara RA, Sperling L, Ewell P, Kirkby R. The role of research institutions in seed-related disaster relief: seeds of hope experiences in Rwanda. Disasters. 2002:26:288-301.

73. Chapagain T, Good A. Yield and production gaps in rainfed wheat, barley, and canola in Alberta. Front Plant Sci. 2015;6:990. doi:10.3389/ fpls.2015.00990.

74. Chapagain T, Riseman A. Evaluation of heirloom and commercial cultivars of small grains under low input organic systems. Am J Plant Sci. 2012;3(5):655. doi:10.4236/ajps.2012.35080.

75. Chapagain T, Super L, Riseman A. Root architecture variation in wheat and barley cultivars. Am J Exp Agric. 2014;4(7):849-56. doi:10.9734/ AJEA/2014/9462

76. Mulvey JM, Awan SW, Qadri AA, Maqsood MA. Profile of injuries arising from the 2005 Kashmir earthquake: the first 72 h. Injury. 2008;39:554-60.

77. Essex J. The work of hunger: security, development, and food-for-work in post crisis Jakarta. Stud Soc Justice. 2009:3:99-116.

78. Moore S, Daniel M, Eng E. International NGOs and the role of network controlling in humanitarian aid operation: a case study of coordination during the 2000 Mozambique floods. Disasters. 2003;27:305-18.

79. Rhodes L. Haitian heroines: women are the backbone of Haiti's market system. But they need help_-desperately. Int Econ. 2001;15:38-42.

80. UN OCHA [United Nations Office for the Coordination of Humanitarian Affairs]. Cluster coordination. http://www.unocha.org/what-we-do/ coordination-tools/cluster-coordination. Accessed 27 Mar 2017.

81. Humphries V. Improving humanitarian coordination: common challenges and lessons learned from the cluster approach. http://sites.tufts.edu/jha/ archives/1976. Accessed 27 Mar 2017

82. Shaw $R$, Sinha R. Towards sustainable recovery: future challenges after the Gujarat earthquake. Risk Manag. 2003;5:35-51.

\section{Submit your next manuscript to BioMed Central and we will help you at every step:}

- We accept pre-submission inquiries

- Our selector tool helps you to find the most relevant journal

- We provide round the clock customer support

- Convenient online submission

- Thorough peer review

- Inclusion in PubMed and all major indexing services

- Maximum visibility for your research

Submit your manuscript at www.biomedcentral.com/submit
O Biomed Central 